\title{
Erratum
}

Due to an unfortunate error, the name of the Communicating Editor for the article "Molecular analysis of the capsid protein gene of a german isolate of barley mild mosaic virus" by U. Schlichter, A. Sohn, E. Peerenboom, J. Schell, and H.-H. Steinbiß in Volume 12, issue 4, 1993 pp. 237-240 was incorrect. The correct information is given below:

Plant Cell Reports (1993) 12:237-240

\section{Molecular analysis of the capsid protein gene of a german isolate of barley mild mosaic virus}

\author{
U. Schlichter, A. Sohn, E. Peerenboom, J. Schell, and H.-H. Steinbil \\ Max-Planck-Institut für Züchtungsforschung, Abteilung Grundlagen der Pflanzenzüchtung, Carl-von-Linné Weg 10, W-5000 Köln 30, FRG
}

Received August 24, 1992/Revised version received December 4, 1992 - Communicated by H. Lörz 